PressAcademia Procedia

YEAR 2020 VOLUME 12

Istanbul Finance Congress, November 5-6, 2020

\title{
ANALYSIS OF THE RELATIONSHIP BETWEEN INTELLECTUAL CAPITAL AND FIRM PERFORMANCE: AN EMPIRICAL RESEARCH ON BORSA ISTANBUL
}

\author{
DOI: 10.17261/Pressacademia.2020.1341 \\ PAP- V.12-2020(5)-p.21-26
}

\section{Mesut Dogan ${ }^{1}$, Mustafa Kevser ${ }^{2}$}

${ }^{1}$ Afyon Kocatepe University, Accounting and Tax Applications Department, Afyon, Turkey. mesutdogan07@gmail.com, ORCID: 0000-0001-6879-1361

2Bandırma Onyedi Eylul University, Finance, Banking and Insurance,Balıkesir, Turkey. mkevser@bandirma.edu.tr, ORCID: 0000-0003-0586-1662

\section{To cite this document}

Dogan, M., Kevser, M. (2020). Analysis of the relationship between intellectual capital and firm performance: an empirical research on Borsa Istanbul. PressAcademia Procedia (PAP), V.12, p.21-26.

Permemant link to this document: $\mathrm{http} / / /$ doi.org/10.17261/Pressacademia.2020.1341

Copyright: Published by PressAcademia and limited licenced re-use rights only.

\section{ABSTRACT}

Purpose- The purpose of this research is to reveal the effect of firms' intellectual capital on financial performance. Firms invest in intangible assets as well as tangible assets in order to gain competitive advantage (Atan ve Tuncer, 2019). Within the scope of intangible fixed assets, the most investment is made to intellectual capital. Intellectual capital has three basic dimensions: human capital, structural capital and customer capital (Soylu, 2020). In the 21st century, where technology changes and develops very rapidly, companies create added value by using their intellectual capital and turn the added value into profit. In this respect, intellectual capital is knowledge that can turn into profit (Çetin, 2005).

Methodology- The intellectual capital levels of companies operating in the Borsa Istanbul Industrial Index were measured by the Intellectual Value Added Coefficient (VAIC) method for the period of 2015-2019. The relationship between the obtained coefficient and financial performance indicators, return on assets ratio (ROA), return on equity (ROE) and Tobin's $Q$ ratio, was analyzed by panel data method.

Findings- According to the results of the research, there is a statistically significant and positive relationship between the intellectual capital coefficient and profitability rates and Tobin's $Q$ ratio.

Conclusion- The results obtained show the positive effect of intellectual capital on firm performance. Companies can focus on intellectual capital investments and increase their productivity for sustainable financial performance.

Keywords: Intellectual capital, ROA, ROE, Tobin's Q, intellectual value added coefficient. JEL Codes: C61, E22, G30

\section{INTRODUCTION}

Intellectual capital is information and information-based intangible assets that provide a competitive advantage by improving the innovation and creativity of the enterprise. The most important main elements of intellectual capital; human capital, structural capital and relational capital (Atan ve Tuncer, 2009). Marr et al. (2003) argue that a firm's value is often partly based on the intangible intellectual capital (IC) that it possesses. By intellectual capital, it is meant the specific and valuable knowledge that belongs to the organization. This qualification of intellectual capital as a strategic asset rests on a potential link between intellectual capital on one hand and firm performance on the other hand (Belkaoui, 2003). There are very few studies investigating the relationship between IC and firm performance bu using VAIC method especially in the context of Turkey. Accordingly the purpose of this study is to examine the effect of IC on Turkish industrial firms which are operating in Borsa Istanbul (BIST).

\section{LITERATURE REVIEW}

Different results have been obtained from studies analyzing the relationship between intellectual capital and firm performance. Maditinos et al. (2011) found only a statistically significant relationship between human capital efficiency and financial performance. Clarke et. al, (2011) found a direct relationship between value added intellectual capital (VAIC) and performance of Australian publicly listed firms, particularly with capital employed efficiencies (CEE) and to a lesser extent with human capital efficiencies (HCE). A positive relationship between HCE and structural capita efficiencies (SCE) in the prior year and performance in the current year is also found. However evidence also suggests 
the possibility of an alternative moderating relationship between the intellectual capital (IC) components of HCE and SCE with physical and financial capital (CEE) which impacts on firm performance. According to Wang et. al., (2014) three dimesions of intellectual capital enhance both operational and financial performance of firms. Also the effect of knowledge sharing (KS) on firm performance is mediated by IC. Gülcemal and Çıtak (2017) stated that intellectual capital levels measured with VAIC correlate with the performance of firms and can be considered as a leading indicator of performance.

\section{DATA AND METHODOLOGY}

The intellectual capital levels of companies operating in the Borsa Istanbul Industrial Index were measured by the Intellectual Value Added Coefficient (VAIC) method for the period of 2015-2019. The relationship between the obtained coefficient and financial performance indicators, return on assets ratio (ROA), return on equity (ROE) and Tobin's Q ratio, was analyzed by panel data method. We also used unit root tests, Hausman tests, auto-correlation tests, inter unit correlation tests, multiple variance tests and Beck-Katz (1995) robust estimator.

\section{FINDINGS}

Before developing a model in a panel data analysis, it is necessary to look at the stationarity of the series, in other words, the stability of the process that creates those series over time. When statistical analysis is performed with unit root data, misleading regression can occur with results, that is, traditional $F, R^{2}$ and t test values give results in a deviating way. Therefore, unit root tests should be done first (Tatoğlu, 2013).

Table 1: PP Fisher Test Panel Unit Root Test Results

\begin{tabular}{|c|c|c|}
\hline \multirow{2}{*}{ VARIABLE } & \multicolumn{2}{|c|}{ PP Fisher Test } \\
\cline { 2 - 3 } & Statistics & P \\
\hline ASSET & 331,55 & 0,000 \\
\hline ROA & 642,34 & 0,000 \\
\hline TOBIN & 531,97 & 0,000 \\
\hline LEVERAGE & 1092,11 & 0,000 \\
\hline ROE & 1023,63 & 0,000 \\
\hline VAIC & 531,32 & 0,000 \\
\hline
\end{tabular}

The following hypotheses have been developed while determining the stationarity of dependent and independent variables.

$\mathrm{H}_{0}$ : There is a general unit root in the series $(\mathrm{HO}: \mathrm{pi}=\mathrm{p}=1)$.

$\mathrm{H}_{1}$ : There is no general unit root in the series $(\mathrm{HO}=\mathrm{pi}=\mathrm{p}<1)$.

Table 1 examines the stationarity of the variables. In order to find a significant relationship between series in statistical analysis, variables should not have a unit root. If there is a trend in the time series for the variable, the relationship may be false. For this reason, whether it is a false relationship or a real relationship in regression models is related to the stability of the variables (Sevinç, 2013). Unit root tests are divided into 2 groups as second and first generation tests. Authors such as Pesaran (2004), Philips and Sul (2003), Moon and Bai and Ng (2004), Perron (2004) developed second-generation tests. The first generation tests were derived by Haris and Tzavalis (1999), Levin, Lin and Chu (LLC) (2002), Fisher Philips and Perron (PP-Fisher ADF), Im, Pesaran, and Shin (1997). As it can be understood from Table 1, the tested unit root test results indicate that there is no unit root in the variables, that is, it is stationary. In other words, the null hypothesis (HO) claiming that the series are unit roots due to the stationarity of the variables is not accepted.

Table 2: Hausman Test

\begin{tabular}{|c|c|c|}
\hline Models & Chi' $^{2}$ test & P \\
\hline Model 1 & 29,53 & 0,000 \\
\hline Model 2 & 21,74 & 0,000 \\
\hline Model 3 & 27,32 & 0.000 \\
\hline
\end{tabular}

$\mathrm{H}_{0}$ : There are random effects.

$\mathrm{H}_{1}$ : There are no random effects.

In the analysis, Hausman Test was used to decide which of the random effects and fixed effects methods to be decided. As a result of the said Hausman test, the coefficients determined in the random effects model are compared with the coefficients determined in the fixed effects model, if a significant relationship ( $p>0.05$ ) between the coefficients cannot be determined, the random effects model is used. However, if there is a significant relationship ( $p<0.05)$, it is suggested that the fixed effects model should be used (Ocak, 2013). Fixed effects models perceive their effects as a fixed term specific to the company, incorporating some individual characteristics and their fixed properties over time and these remain constant over time. In order to benefit from the fixed effects technique, some effects must be found and the effects must remain constant over time (Greene, 2000). In the random effects technique, different from the fixed effects technique, the 
mean and variances of the effect belonging to the horizontal section come from the distribution. In the random effects technique, the horizontal cross section effects are assumed to come from the random distribution (Uludağ and Gökmen, 2010).

In Table 2, Hausman test was used to decide whether there are random or fixed effects in the panel data analysis model. In general, random effects and fixed effects techniques give similar results. When looking at the results of Hausman test, it states that choosing the fixed effects model will give more valid and accurate outputs since the determined p value is less than 0.05 . In other words, the null hypothesis, stating that the effects of firms and years used in the models are random and stating that there is no correlation between explanatory variables and $\varepsilon$, was rejected. The companies used in the fixed model and the hypothesis that the effect of years is fixed and that there is a correlation between the explanatory variables and $\varepsilon$ was accepted. Since the null hypothesis is rejected, fixed effects model should be used instead of random effects model.

Table 3: Auto-correlation Test Results

\begin{tabular}{|c|c|c|}
\hline Models & $\begin{array}{c}\text { Baltagi-Wu's Local Best Fixed Test } \\
\text { (LBI) }\end{array}$ & $\begin{array}{c}\text { Durbin Watson test of Bhargava, } \\
\text { Franzini and Narendranathan }\end{array}$ \\
\hline Model 1 & 2,74 & 2,29 \\
\hline Model 2 & 2,46 & 2,41 \\
\hline Model 3 & 2,51 & 2,31 \\
\hline
\end{tabular}

The following hypotheses have been developed in order to test the auto-correlation of variables.

$\mathrm{H}_{0}$ : There is no first order autocorrelation.

$\mathrm{H}_{1}$ : There is first order autocorrelation.

One of the assumptions of the regression analysis is that there is no correlation between the same errors. Error in the model means that there is auto-correlation in the model if the terms are related. In other words, violation of the assumption that the correlations between successive error terms (ut) are equal to 0 is stated as autocorrelation. If there is no auto-correlation between ut and ut-1, this means that the expected values and covariances are equal to 0 . If there is autocorrelation in the model, the OLS estimators of the parameters are consistent and without bias, however, they lose their efficiency functions. Therefore, in case of autocorrelation, variance estimators of the error term are deviated. In this case, parameter estimators are not effective and their variances are deviated (Yildırtan, 2011).

It is not correct to use Durbin-Watson or Breusch-Godfrey tests in the model developed in panel data analysis to determine the presence of auto-correlation (Bhargava, Franzini, \& Narendranathan, 1982). Instead of these techniques, Baltagi-Wu's Local Best Invariant Test (LBI) and Durbin Watson test of Bhargava, Franzini and Narendranathan, which were developed for panel data analysis, were used. The existence of auto-correlation in the model developed in Table 3 was determined by these techniques. According to these methods, if the values are smaller than two, it means that there is autocorrelation. As a result, the null hypothesis could not be rejected for the models.

Table 4: Results of the Inter-Unit Correlation Test

\begin{tabular}{|c|c|c|}
\hline \multirow{2}{*}{ Models } & \multicolumn{2}{|c|}{ Pesaran Test } \\
\cline { 2 - 3 } & Value & $\mathbf{P}$ \\
\hline Model 1 & 20.511 & 0,0000 \\
\hline Model 2 & 20.542 & 0,0000 \\
\hline Model 3 & 19,672 & 0,0000 \\
\hline
\end{tabular}

The following hypotheses have been developed as a result of the multiple cross-section dependency test for the variables.

$\mathrm{H}_{0}$ : There is no cross section dependency.

$\mathrm{H}_{1}$ : There is cross section dependence

It is one of the assumptions of the panel data model that error terms are independent of units. However, there may be simultaneous correlation of errors along the cross section units. In this case, there is heteroskedacty and autocorrelation and the correlation matrix prevents it from becoming an identity matrix. Therefore, it is necessary to test the non-correlation between units, which is its basic hypothesis (Tatoğlu, 2013). Pesaran Test was used to detect this non-correlation in the study. Pesaran (2004) proposes it as an alternative to the BreuschPagan test to determine the correlation between units under conditions where $\mathrm{N}$ is large and $\mathrm{T}$ is small.

In Table 4, Pesaran CD test was used to determine the correlation between units in the fixed effects model and to measure the cross-sectional dependency. When looking at the results, it is seen that the model has a cross-sectional dependency since the $p$ value is less than 0.05 , that is, there is a correlation between units. As a result, the $\mathrm{H}_{0}$ hypothesis was rejected. 
Table 5: Results of Multiple Variance Test

\begin{tabular}{|c|c|c|}
\hline \multirow{2}{*}{ Models } & \multicolumn{2}{|c|}{ Modified Wald Test } \\
\cline { 2 - 3 } & Chi2 & P \\
\hline Model 1 & 6732.43 & 0,001 \\
\hline Model 2 & 7841.12 & 0,000 \\
\hline Model 3 & 7034.31 & 0,001 \\
\hline
\end{tabular}

The following hypotheses have been developed as a result of the multiple variance tests for the variables used in the study.

$\mathrm{H}_{0}$ : There is no changing variance.

$\mathrm{H}_{1}$ : There is varying variance.

Constant variance is one of the basic assumptions about the regression's error term. If the fixed variance assumption is not valid, this situation is expressed as changing variance. That is, if the variance of $\mathrm{Bi}$ increases as $\mathrm{A}$ increases in the model, it means that $\mathrm{Bi}$ does not have the same variance (Kutlar \& Babacan, 2012). If the fixed variance assumption is not valid, there may be an effect on all issues related to the model starting from the parameter estimator (Güriş, Çağlayan, \& Güriş, 2013). In case of varying variance, OLS estimators can be unbiased, but the hypothesis test may lose its validity because the covariance and variance estimators are not effective. However, prediction and estimation intervals may expand at a certain level of significance (Albayrak, 2008).

In Table 5, Modified Wald test was used to test the existence of multiple variance problem in the model. Standard Wald, LR, LM tests are used in panel data analysis only if the error is assumed to be normally distributed. On the other hand, Modified Wald Test is also used in the absence of normal distribution (Tatoğlu, 2013). Looking at Table 5, the HO hypothesis was rejected because the $\mathrm{p}$ value for the developed model was less than 0.05 . In other words, there is a variance problem in the model. As a result, the variance varies according to the units and therefore it is heteroskedasite.

\section{Table 6: Robust Estimator Results (Model 1)}

\begin{tabular}{|c|c|c|c|c|}
\hline \multicolumn{5}{|c|}{$\begin{array}{l}\text { Dependent Variable: ROA } \\
\text { Years: } 2015-2019 \\
\text { Number of Years: } 5 \\
\text { Company Observations: } 110 \\
\text { Total Number of Observations: } 550\end{array}$} \\
\hline Variables & Efficiency & Std. Dev. & t-statistics & P Value \\
\hline VAIC & .3211 & .0210 & 9.43 & 0.000 \\
\hline ASSET & .1131 & .032 & 7.33 & 0.000 \\
\hline LEVERAGE & -.3422 & .0291 & -11.02 & 0.000 \\
\hline Wald chi2 & \multicolumn{4}{|c|}{179.22} \\
\hline P Statistics & \multicolumn{4}{|c|}{0.0000} \\
\hline $\mathrm{R}^{2}$ & \multicolumn{4}{|c|}{0.1612} \\
\hline
\end{tabular}

In the regression model, in case of inter-unit correlation, auto-correlation and heteroskedasite, the variance of the unit matrix and error term is not equal to each other. This situation causes inconsistency in the model to be developed and affects the effectiveness of the model. Therefore, in the case of at least one of the problems of autocorrelation and heteroscedasticity, the correlation between units in the model should either be estimated by appropriate methods or standard errors should be corrected without touching the parameter estimates (Tatoğlu, 2013). Although the least-squares technique is popular in the regression model in the literature, robust estimators have been used in this study for these reasons. Robust estimators in the literature are Kmenta (1986), Driscoll and Kraay (1998), Eicker (1967), Newey-West (1994), White (1980), Froot (1989), Parks (1967), Huber (1967), Rogers (1993), Wooldridge (2002), Anselin (1988), Arellano (1987), Beck-Katz (1995) proposed authors. In the study, standard errors were corrected with the help of robust estimator developed by Beck-Katz (1995), since the correlation between units is resistant to the existence of autocorrelation and variance and can be applied in case of $\mathrm{T}<\mathrm{N}$ or increased predictive power. As a result, the Beck-Katz (1995) estimator prevents autocorrelation, correlation between units and variance problems.

In Table 6, robust estimator results showing the relationship between ROA and intellectual capital (VAIC) are shown. In this developed model, the data of 110 companies for the years 2015-2019 were used. As can be seen from Table 6, autocorrelation, inter-unit correlation and variance problems have been prevented by Beck-Katz (1995) estimator, and in this model, the F statistic level is statistically significant and the model has sufficient explanatory power. In addition, the changes in ROA are explained with $16 \%$ independent variables. However, $16 \%$ of the "coefficient of determination" $\left(R^{2}\right)$ was used to determine the relative efficiency of the model. When the relationships between the variables are examined, it is understood that there is a statistically positive and significant relationship between ROA and VAIC. In other words, as the intellectual capital of firms increases, their asset profitability increases. In addition, leverage, assets variables are effective on 
ROA. There is a positive relationship between ROA and total assets (ASSET), which is the indicator of firm size, whereas there is a negative relationship with leverage ratio.

\section{Table 7: Robust Estimator Results (Model 2)}

\section{Dependent Variable: ROE}

Years: 2015-2019

Number of Years: 5

Company Observations: 110

Total Number of Observations: 550

\begin{tabular}{|c|c|c|c|c|}
\hline Variables & Efficiency & Std. Dev. & t-statistics & P Value \\
\hline VAIC & .273 & .0153 & 10.23 & $\mathbf{0 . 0 0 0}$ \\
\hline ASSETS & .1211 & .0231 & 6.42 & $\mathbf{0 . 0 0 1}$ \\
\hline LEVERAGE & -.3477 & .0521 & -11.64 & $\mathbf{0 . 0 0 0}$ \\
\hline Wald chi2 & \multicolumn{3}{|c|}{0.0000} \\
\hline P Statistics & \multicolumn{3}{|c|}{0.1434} \\
\hline $\mathrm{R}^{2}$ & \multicolumn{5}{|l}{} \\
\hline
\end{tabular}

In Table 7, robust estimator results showing the relationship between ROE and intellectual capital (VAIC) are shown. When the relationships between the variables are examined, it is understood that there is a statistically positive and significant relationship between ROE and VAIC. In other words, as the intellectual capital of firms increases, their equity profitability increases. In addition, leverage, asset variables are effective on ROE. In addition, there is a positive relationship between ROE and total assets (ASSET), which is the indicator of firm size, whereas there is a negative relationship with leverage ratio.

Table 8: Robust Estimator Results (Model 3)

\section{Dependent Variable: TOBIN}

Years: 2015-2019

Number of Years: 5

Company Observations: 110

Total Number of Observations: 550

\begin{tabular}{|c|c|c|c|c|}
\hline Variables & Efficiency & Std. Dev. & t-statistics & P Value \\
\hline VAIC & 1.231 & .0253 & 18.43 & $\mathbf{0 . 0 0 0}$ \\
\hline VARLIK & .043 & .0231 & .424 & 0.532 \\
\hline KALDIRAC & -.0023 & .0363 & -.132 & 0.702 \\
\hline Wald chi2 & \multicolumn{5}{|c|}{0.02 .43} \\
\hline P İstatistiği & \multicolumn{5}{|c|}{0.102} \\
\hline$R^{2}$ & \multicolumn{5}{|c|}{0} \\
\hline
\end{tabular}

In Table 8, robust estimator results showing the relationship between TOBIN and intellectual capital (VAIC) are shown. When the relationships between the variables are examined, it is understood that there is a statistically positive and significant relationship between TOBIN and VAIC. In other words, as the intellectual capital of the firms increases, the tobin's q ratio also increases. On the other hand, leverage, asset variables do not affect Tobin's q ratio.

\section{CONCLUSION}

According to the results of the research, there is a statistically significant and positive relationship between the intellectual capital coefficient and profitability rates and Tobin's $Q$ ratio. The results obtained show the positive effect of intellectual capital on firm performance. According to the results of the research, there is a statistically significant and positive relationship between the intellectual capital coefficient and profitability rates and Tobin's $Q$ ratio. The results obtained show the positive effect of intellectual capital on firm performance. Companies can focus on intellectual capital investments and increase their productivity for sustainable financial performance.

\section{REFERENCES}

Albayrak, A. S. (2008). Değişen varyans durumunda en küçük kareler tekniğinin alternatifi ağırlıklı regresyon analizi ve bir uygulama. Afyon Kocatepe Üniversitesi, I.I. B.F. Dergisi, 10(2): 111- 134.

Atan, Ö., Tunçer, A. (2019). Entelektüel sermayenin işletme performansına etkileri üzerine bir araştırma. Haliç Üniversitesi Sosyal Bilimler Dergisi, 2(1): 71-100.

Belkaoui, A.R. (2003). Intellectual capital and firm performance of US multinational firms A study of the resource-based and stakeholder views. Journal of Intellectual Capital, 4(2): 215-226. 
Bhargava, A., Franzini, L., Narendranathan, W. (1982). Serial correlation and the fixed effects model. Review of Economic Studies, 49: 533549 .

Clarke, M., Seng, D., Whiting, R.H. (2011). Intellectual capital and firm performance in Australia. Journal of Intellectual Capital, 12(4): 505530 .

Çetin, A. (2005). Entelektüel sermaye ve ölçülmesi. Marmara Üniversitesi i.i.B.F. Dergisi, 20(11): 359-378.

Greene, W. H. (2000). Econometric Analysis. New Jarsey: Prentice Hall.

Gülcemal, T., Çıtak, L. (2017). Entelektüel katma değer katsayısı yöntemi ile ölçülen entelektüel sermayenin firma performansı üzerindeki etkisi. Celal Bayar Üniversitesi Iktisadi ve Idari Bilimler Dergisi, 18(1): 35-55.

Güriş, S., Çağlayan, E., Güriş, B. (2013). Eviews ile Temel Ekonometri (2.Baskı). İstanbul: Der Yayınları.

Marr, B., Gray, D., Neely, A. (2003). Why do firms measure their intellectual capital. Journal of Intellectual Capital, 4(4): 441-64.

Maditinos, D., Chatzoudes, D., Tsairidis, C., Georgios Theriou, G. (2011). The Impact of intellectual capital on firms' market value and financial performance. Journal of Intellectual Capital, 12 (1): 132-151.

Ocak, M. (2013). yönetim kurulu ve üst yönetimde yer alan kadınların finansal performansa etkisi: Türkiye'ye ilişkin bulgular. Muhasebe ve Finansman Dergisi, 60: 107- 126.

Sevinç, V. (2013). Türkiye'ye gelen yabancı turist sayısı, amerikan doları kuru ve ekonomik kriz yılları arasında bir granger nedensellik ilişkisi analizi. Ekonomik ve Sosyal Araştırmalar Dergisi, 9(2): 233- 249.

Soylu, N. (2020). Entelektüel sermaye etkinliğinin veri zarflama analizi ile değerlendirilmesi: BIST teknoloji şirketlerine yönelik bir araştırma. Muhasebe ve Finansman Dergisi, 85:269-286.

Tatoğlu, F. Y. (2013). Panel Veri Ekonometrisi (2. Baskı). İstanbul: Beta Yayınevi.

Tatoğlu, F. Y. (2013). Illeri Panel Veri Analizi (2.Baskı). İstanbul: Beta Yayınevi.

Uludağ, B. K., Gökmen, H. (2010). Türk bankacılık sektörünün kârlılı̆ının dinamik yaklaşımla test edilmesi, 14. Ulusal Finans Sempozyumu, Selçuk Üniversitesi Iktisadi ve Idari Bilimler Fakültesi, 3 - 6 Kasım 2010 - Konya, 135- 152.

Wang, Z., Wang, N., Liang, H. (2014). Knowledge sharing, ,intellectual capital and firm performance. Management Decision, 52(2): $230-258$. 